\title{
NOTE
}

\section{Oxygen conditions on surfaces of coralline red algae}

\author{
Heinrich F. Kaspar* \\ Institute of Ecology and Genetics, University of Århus, Ny Munkegade, DK-8000 Århus C, Denmark
}

\begin{abstract}
Oxygen profiles above coralline algal surfaces were measured with micro-electrodes. At flow velocities of 1 to $3 \mathrm{~cm} \mathrm{~s}^{-1}$ in the mixed layer, the diffusive boundary layer was 0.1 to $0.2 \mathrm{~mm}$ on algae which were frequently grazed by limpets and chitons. It extended to $0.5 \mathrm{~mm}$ above surfaces on which a microbial film had developed after $16 \mathrm{~d}$ without grazing. When the mixed layer above grazed algae was not stirred the diffusive boundary layer reached $2.5 \mathrm{~mm}$. The lowest $\mathrm{O}_{2}$ concentration on the algal surface was $11 \%$ of air saturation (Lithothamnion sp. dark, unstirred), and the highest concentration was $397 \%$ of air saturation (Lithothamnion, light, unstirred). With a flow velocity of 1 to $3 \mathrm{~cm} \mathrm{~s}^{-1}$ in the mixed layer, the corresponding range was 53 to $211 \%$ of air saturation. The $\mathrm{O}_{2}$ consumption rate was $0.8 \mathrm{mmol} \mathrm{m} \mathrm{m}^{-2} \mathrm{~h}^{-1} \mathrm{O}_{2}$ production rates at light saturation were $3.2 \mathrm{mmol} \mathrm{m}^{-2} \mathrm{~h}^{-1}$ (Corallina sp.) and $10.4 \mathrm{mmol} \mathrm{m}^{-2} \mathrm{~h}^{-1}$ (Lithothamnion). For a Lithothamnion sp. the compensation point was at $10 \mu \mathrm{mol}$ quanta $\mathrm{m}^{-2} \mathrm{~s}^{-1}$, and the photosynthetic $\mathrm{O}_{2}$ production was saturated at 50 to $100 \mu \mathrm{mol}$ quanta $\mathrm{m}^{-2} \mathrm{~s}^{-1}$ The biofilm which developed in the absence of grazers increased the $\mathrm{O}_{2}$ consumption of the surfaces, but no anaerobiosis was observed on coralline surfaces under any of the conditions tested.
\end{abstract}

Coralline algae (Rhodophyta, Corallinaceae) can be found in the photic subtidal of most rocky sea coasts (Johansen 1981). Despite their slow growth, corallines compete successfully for large proportions of the hard substratum under a wide variety of environmental conditions. Intensive grazing appears to be important for the prevention of overgrowth and thus for the longterm survival of coralline algae in many natural habitats (Steneck 1986). Limpets, chitons, abalone, sea urchins and finfish are among the herbivores capable of keeping the coralline surface clean.

The coralline algae provide food and shelter for the newly-settled larvae and juveniles of at least some of

\footnotetext{
- Permanent address: Cawthron Institute, Private Bag, Nelson, New Zealand
}

their regular grazers, thus acting as their nursery ground (Garland et al. 1985). Coralline surfaces are uniquely able to induce the planktonic larvae of abalone (Haliotis) to settle and metamorphose (Morse \& Morse 1984). There appear to be mutual benefits in the coralline-grazer association: grazers keep the corallines free from soft algal colonizers, and the corallines provide a suitable habitat for larval settlement.

The ecologically significant inducers of abalone larval settlement are organic substances which are often assumed to originate from the corallines (Morse \& Morse 1984). However, coralline surfaces are colonized by bacteria, despite the frequent and intensive scouring (Lewis et al. 1985, Johnson et al. 1991). These bacteria may affect the larval settlement of abalone and possibly other grazers (e.g. sea urchins; Pearce \& Scheibling 1990) by producing and/or degrading settlement-inducing molecules (Kaspar et al. 1989, Johnson et al. 1991).

The metabolism of newly-settled larvae, post-larvae, juveniles and microbial colonizers on the coralline surfaces is affected by the oxygen concentration in the diffusive boundary layer (DBL) between the surface and the mixed water above the surface (Revsbech \& Jørgensen 1986). The oxygen concentration is the result of oxygen consumption and production rates by the algae/microbes/grazers community and of the diffusion rate across the DBL. This paper describes the oxygen conditions on the coralline surfaces as affected by respiration, photosynthesis, water movement and grazing.

Materials and methods. Fist-size stones which were colonized by coralline algae (Lithothamnion sp. and Corallina sp.), foliose red and brown algae and the associated fauna (e.g. chitons, limpets) were collected on 24 February and 3 March 1991 at 0.5 to $1.5 \mathrm{~m}$ depth 
from Limfjorden near the Rønbjerg field station of the University of Arhus, Denmark. The stones were kept submerged in seawater and brought to the laboratory where they were placed in aquaria containing aerated seawater ( $27 \%$ salinity, 18 to $21^{\circ} \mathrm{C}$ ) and exposed to natural light fluctuations.

Oxygen measurements were started after a 2 wk adaptation period. Individual stones were placed in an aquarium under the same conditions as above. A micromanipulator was used to lower a microelectrode with guard cathode (Revsbech 1989) vertically onto the coralline surfaces. The signal was measured with a picoammeter and recorded with a strip chart recorder. Further details are given by Revsbech \& Jørgensen (1986). Aeration at a constant rate provided for water flow velocities of 1 to $3 \mathrm{~cm} \mathrm{~s}^{-1}$ and oxygen concentrations at equilibrium with air in the mixed layer near the electrode. The aquarium was wrapped in black plastic for dark incubations. A TCT-W Type FL fibreoptics light source (Lyngså, Saeby, Denmark) was used for light incubations. Light measurements were done with a Model LI-185A quantum photometer and a LI-190S quantum sensor (LI-COR Inc, Lincoln, Nebraska).

The effect of grazing was determined on a stone which was kept in a separate aquarium without grazers for $16 \mathrm{~d}$ before the first oxygen profiles were taken. Five limpets ( 1 to $2 \mathrm{~cm}$ diameter) were then placed on the stone overnight, and on the following day the measurements were repeated above areas of the surface which had been grazed clean by the limpets.

The diffusive boundary layer (DBL) was defined as the area between the coralline surface and the distance from this surface at which the oxygen concentration first reached equilibrium with air (Jørgensen \& Revsbech 1985). The flux of oxygen through the DBL was calculated from the linear portion of the oxygen gradient, using Fick's first law of diffusion (Revsbech \& Jørgensen 1986). The profiles were measured in at least 4 replicates within a few mm of each other. Standard deviations were less than $13 \%$ of the mean for all measurements. They are given in Fig. 1 but left out for clarity in the other figures.

Results and discussion. Under dark and stirred conditions the oxygen concentration at 4 sites on a Corallina sp. surface was 93 to $98 \%$ of air saturation. On a Lithothamnion sp. surface the range was 53 to $95 \%$ when stirred and 11 to $69 \%$ when unstirred (13 measurements). The lowest oxygen concentrations were at the bottom of conceptacles where the DBL was likely to be thickest (Jørgensen \& Des Marais 1990).

The thickness of the DBL is a major controlling factor of the oxygen concentration on the coralline algal surface. At water flow velocities of 1 to $3 \mathrm{~cm} \mathrm{~s}^{-1}$ in the mixed layer the DBL was 0.1 to $0.2 \mathrm{~mm}$ (Figs. 1, 2 \& 3). Under similar conditions, DBL thicknesses of 0.2 to $>1 \mathrm{~mm}$ over sediments (Jørgensen \& Revsbech 1985) and 0.16 to $0.59 \mathrm{~mm}$ over an algal mat (Jorgensen \& Des Marais 1990) have been reported. The thinner DBL over corallines is not surprising in view of their smooth, well-defined surface which is normally kept free of colonizers by frequent grazing and sloughing of the epithallium (Johnson \& Mann 1986, Steneck 1986). Under stirred conditions, the coralline surface provided for a relatively thin DBL and thus a small diffusive barrier. After stirring had been stopped, the DBL expanded to $2.5 \mathrm{~mm}$ (Fig. 2). On a Lithothamnion sp. surface which had not been grazed for $16 \mathrm{~d}$ the DBL extended to $0.5 \mathrm{~mm}$ due to the development of a biofilm consisting of detritus, microalgae, protozoans, nematodes and bacteria (Fig. 3).

The demand for oxygen by the coralline algae is the second important factor controlling the oxygen conditions on the algal surface. The $\mathrm{O}_{2}$ uptake rate under stirred conditions was $0.8 \mathrm{mmol} \mathrm{m} \mathrm{m}^{-2} \mathrm{~h}^{-1}$ (calculated from 'dark', 'stirred' and 'after grazing' profiles in Figs. 1,2 \& 3 respectively). This compared with $0.1 \mathrm{mmol} \mathrm{m}^{-2} \mathrm{~h}^{-1}$ in a deep-sea sediment (Reimers \& Smith 1986), 0.5 to $1.8 \mathrm{mmol} \mathrm{m} \mathrm{m}^{-2} \mathrm{~h}^{-1}$ in a saltmarsh (Schwinghamer et al. 1991), 1.1 to $3.8 \mathrm{mmol} \mathrm{m}^{-2} \mathrm{~h}^{-1}$ in coastal sediment (Hopkinson \& Wetzel 1982, Revsbech \& Jørgensen 1986) and 2.7 to $5.3 \mathrm{mmol} \mathrm{m}^{-2} \mathrm{~h}^{-1}$ in a microbial mat of a hypersaline pond (Revsbech et al. 1983). Thus, the coralline algae had a relatively low demand for oxygen.

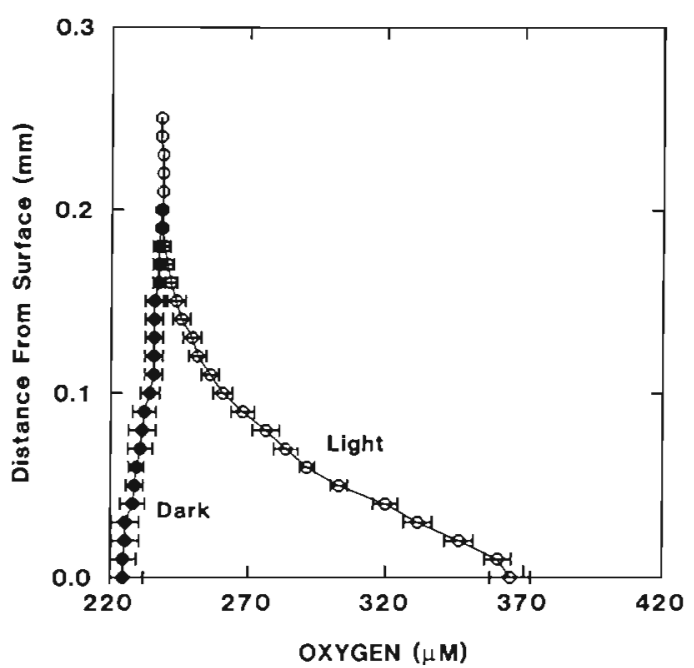

Fig. 1 Oxygen profiles above a Lithothamnion sp. surface under dark and light $\left(100 \mu \mathrm{mol}\right.$ quanta $\left.\mathrm{m}^{-2} \mathrm{~s}^{-1}\right)$ conditions. This surface was frequently grazed by chitons and limpets. Each point represents mean of 5 measurements; bars indicate $\pm 1 \mathrm{SD}$ 


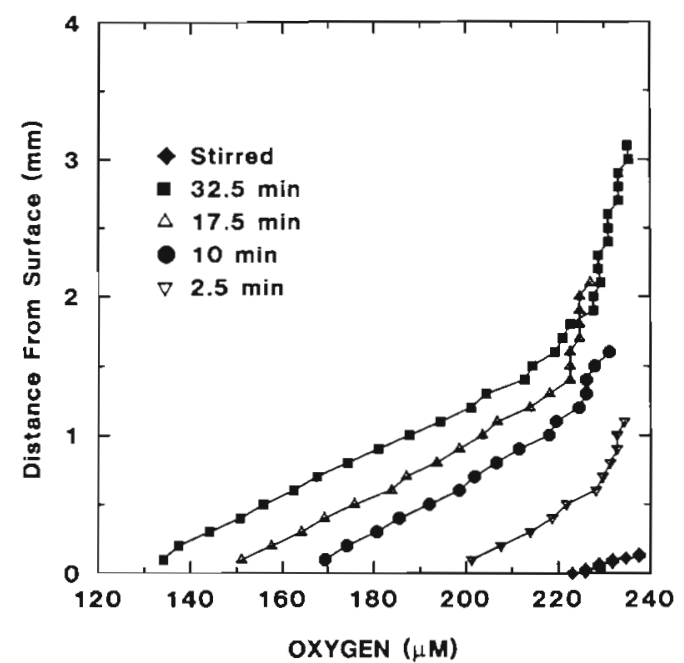

Fig. 2. Dark oxygen profiles in the DBL above a Lithothamnion sp. surface at various times after stirring was stopped. Each point represents 4 measurements. Profiles for 17.5 and 32.5 min are not significantly different

The low oxygen demand, together with a thin DBL, resulted in aerobic conditions on the naturally grazed algal surfaces as well as under conditions favouring oxygen depletion (higher experimental temperature than in situ temperature, no turbulence, increased biofilm thickness due to lack of grazing). The results suggest that small organisms (e.g. invertebrate larvae or bacteria) living in the DBL above the coralline surface may not require an anaerobic energy metabolism. However, it is conceivable that invertebrate larvae, whose diameter is similar to that of conceptacles and the thickness of the DBL, come under oxygen stress in sheltered pockets such as conceptacles.

Incubation of the corallines under light caused the oxygen concentration to increase above the equilibrium with air (Fig. 1). At light saturation, surface oxygen concentrations at 10 sites above a Lithothamnion sp. were 119 to $211 \%$ (stirred) and 245 to $397 \%$ (unstirred) of air saturation. The highest oxygen concentrations were above young vegetative tissue near the fringes of thalli. The net oxygen production calculated from the profile in Fig. 1 was $10.4 \mathrm{mmol} \mathrm{O}_{2} \mathrm{~m}^{-2} \mathrm{~h}^{-1}$. Under similar conditions, a Corallina sp. produced oxygen at $3.2 \mathrm{mmol} \mathrm{m}^{-2} \mathrm{~h}^{-1}$. Wanders (1976) measured 4.7 to $10.6 \mathrm{mmol} \mathrm{m}^{-2} \mathrm{~h}^{-1}$ for coralline crusts and $20 \mathrm{mmol} \mathrm{m}^{-2} \mathrm{~h}^{-1}$ for a dense foliose algal turf. A cyanobacterial mat produced oxygen at $37 \mathrm{mmol} \mathrm{m}{ }^{-2} \mathrm{~h}^{-1}$ (Revsbech \& Jørgensen 1986). For a eucaryotic algal mat $47 \mathrm{mmol} \mathrm{m}^{-2} \mathrm{~h}^{-1}$ has been reported (Revsbech \& Ward 1983). Our results confirm the relatively low photosynthetic oxygen production by corallines. Despite their slow growth, corallines are widespread and often dominate the

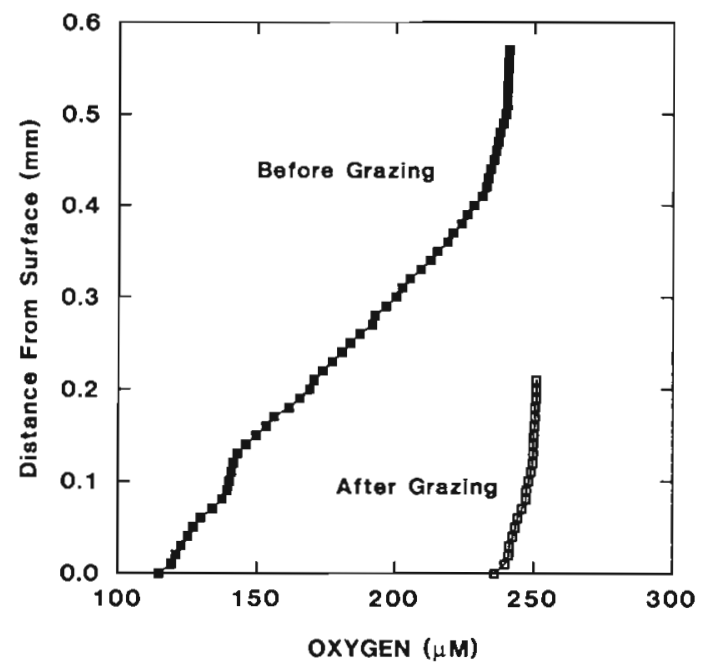

Fig. 3. Dark oxygen profiles in the DBL above a Lithothamnion sp. surface before and after grazing of the biofilm which had developed over a $16 \mathrm{~d}$ period during which grazers (limpets) had been removed. Each point represents the mean of 5 measurements

subtidal vegetation (Johansen 1981). Their success may depend largely on the frequent sloughing of their surface ( Johnson \& Mann 1986) and the grazing by a range of invertebrates whose larvae settle preferentially on corallines (see Johnson et al. 1991, Steneck 1986).

The Lithothamnion sp. used in this work had a compensation point of $10 \mu \mathrm{mol}$ quanta $\mathrm{m}^{-2} \mathrm{~s}^{-1}$, and its photosynthetic oxygen production reached light saturation between 50 and $100 \mu \mathrm{mol}$ quanta $\mathrm{m}^{-2} \mathrm{~s}^{-1}$ (Fig. 4). These results are similar to those reported for other corallines adapted to low light and temperatures (Adey 1973).

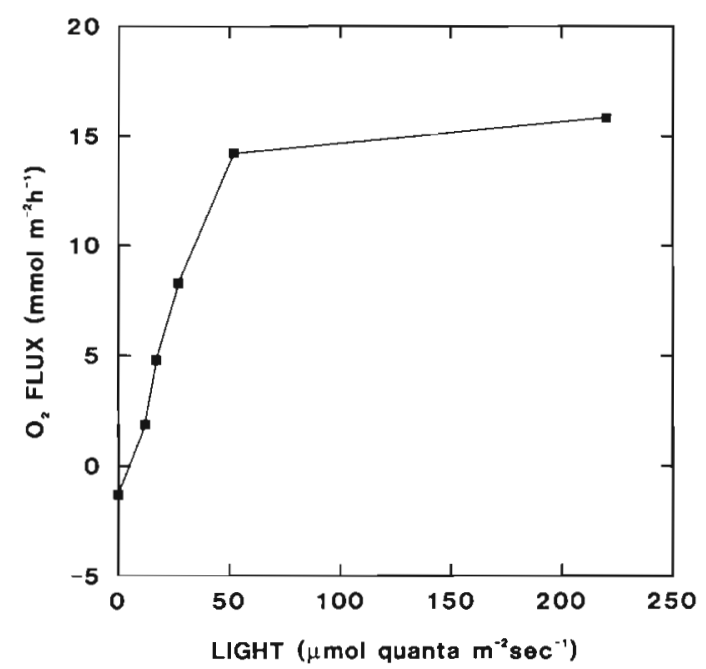

Fig. 4. Oxygen flux across the DBL above a Lithothamnion sp. surface at various light intensities 
A biofilm developed on the coralline surface within a short time after the grazers had been removed (Figs. 1 $\& 3)$. Such a biofilm may prevent the physical contact necessary between invertebrate larvae and the settlement inducers on coralline surfaces (Morse \& Morse 1984), or it may alter the postulated role of bacteria in larval settlement. Due to the extended diffusional barrier it may also lead to an increased concentration of soluble settlement inducers near the surface. The testing of such hypotheses will provide further insight into the interactions between invertebrate larvae and their preferred settlement substrata and produce valuable knowledge for the hatchery-based rearing of juveniles.

Acknowledgements. Thanks go to $\mathrm{T} \mathrm{H}$. Blackburn for giving me the opportunity to work in the Arrhus laboratory and to N. P. Revsbech for the introduction to microelectrodes, valuable practical help and critical review of the manuscript. Anni Glud and Lars Pedersen produced the electrodes. The colleagues at Cawthron Institute and the Institute of Ecology and Genetics made many helpful suggestions for the improvement of the study. The project was in part supported by the New Zealand Foundation for Research, Science and Technology.

\section{LITERATURE CITED}

Adey, W. H. (1973). Temperature control of reproduction and productivity in a subarctic coralline alga. Phycologia 12: $111-118$

Garland, C. D., Cooke, S. L., Grant, J F., McMeekin, T A. (1985). Ingestion of the bacteria on and the cuticle of crustose (non-articulated) coralline algae by post-larval and juvenile abalone (Haliotis ruber Leach) from Tasmanian waters. J. exp. mar. Biol. Ecol. 91: 137-149

Hopkinson, C. S., Wetzel, R. L. (1982). In situ measurements of nutrient and oxygen fluxes in a coastal marine benthic community. Mar. Ecol. Prog. Ser. 10: 29-35

Johansen, H. W. (1981). Coralline algae, a first synthesis. CRC Press, Boca Raton

Johnson, C. R., Muir, D. G., Reysenbach, A. L. (1991). Characteristic bacteria associated with surfaces of coralline algae a hypothesis for bacterial induction of marine invertebrate larvae. Mar. Ecol. Prog. Ser 74: 281-294

Johnson, C. R., Mann, K. H. (1986). The crustose coralline

This note was submitted to the editor alga, Phymatolithon Foslie, inhibits the overgrowth of seaweeds without relying on herbivores. J exp. mar. Biol. Ecol. 96: 127-146

Jørgensen, B. B., Revsbech, N. P. (1985). Diffusive boundary layers and the oxygen uptake of sediments and detritus. Limnol. Oceanogr. 30:111-122

Jorgensen, B. B., Des Marais, D. J (1990). The diffusive boundary layer of sediments: oxygen microgradients over a microbial mat. Limnol. Oceanogr. 35: 1343-1355

Kaspar, H. F., Mountfort, D. O., Pybus, V., Gillespie, P. A. (1989). Degradation of gamma-aminobutyric acid by marine bacteria. In: Miyachi, S., Karube, I., Ishida, Y. (eds.) Current topics in marine biotechnology. The Japanese Society for Marine Biotechnology, Tokyo, p. 421-422

Lewis, T E., Garland, C. D., McMeekin, T A. (1985). The bacterial biota on crustose (nonarticulated) coralline algae from Tasmanian waters. Microb. Ecol. 11: 221-230

Morse, A. N. C., Morse, D. E. (1984). Recruitment and metamorphosis of Haliotis larvae induced by molecules uniquely available at the surfaces of crustose red algae. J. exp. mar. Biol. Ecol. 75: 191-215

Pearce, C. M., Scheibling, R. E. (1990). Induction of metamorphosis of larvae of the green sea urchin, Strongylocentrotus droebachiensis, by coralline red algae. Biol. Bull. mar. biol. Lab., Woods Hole 179: 304-311

Reimers, C. E., Smith, K. L. Jr (1986). Reconciling measured and predicted fluxes of oxygen across the deep sea sediment-water interface. Limnol. Oceanogr. 31: 305-318

Revsbech, N. P. (1989). An oxygen microelectrode with a guard cathode. Limnol. Oceanogr. 34: 474-478

Revsbech, N. P., Jørgensen, B. B. (1986). Microelectrodes: their use in microbial ecology. In: Marshall, K. C. (ed.) Advances in microbial ecology, Vol. IX. Plenum, New York, p. 293-352

Revsbech, N. P., Jørgensen, B. B., Blackburn, T. H., Cohen, Y. (1983). Microelectrode studies of the photosynthesis and $\mathrm{O}_{2}, \mathrm{H}_{2} \mathrm{~S}$, and $\mathrm{pH}$ profiles of a microbial mat. Limnol. Oceanogr. 28: 1062-1074

Revsbech, N. P., Ward, D. M. (1983). Oxygen microelectrode that is insensitive to medium chemical composition: use in an acid microbial mat dominated by Cyanidium caldarium. Appl. environ. Microbiol. 45: 755-759

Schwinghamer, P., Kepkay, P. E., Foda, A. (1991). Oxygen flux and community biomass structure associated with benthic photosynthesis and detritus deposition. J. exp. mar. Biol. Ecol. 147: 9-35

Steneck, R. S. (1986). The ecology of coralline algal crusts: convergent patterns and adaptive strategies. Ann. Rev. Ecol. Syst. 17: 273-303

Wanders, J. B. W. (1976). The role of benthic algae in the shallow reef of Curaç3ao (Netherlands Antilles). I: Primary productivity in the coral reef. Aquat. Bot. 2: 235-270

Manuscript first received: September 24, 1991

Revised version accepted: February 28, 1992 